\title{
Bipolar Strategic Stability in a Multipolar World
}

\author{
Christopher T. Kuklinski ${ }^{1}$, Jeni Mitchell ${ }^{1} \&$ Timothy Sands ${ }^{2}$ \\ ${ }^{1}$ Department of War Studies, King's College London, London WC2R 2LS, United Kingdom \\ ${ }^{2} \mathrm{Fu}$ Foundation School of Engineering and Applied Science (CVN), Columbia University, New York, USA \\ Correspondence: Timothy Sands, Fu Foundation School of Engineering and Applied Science (CVN), Columbia \\ University, New York, USA. Tel: 1-831-656-3954.E-mail: dr.timsands@caa.columbia.edu
}

Received: December 8, 2019

Accepted: January 5, 2020

Online Published: February 29, 2020

doi:10.5539/jpl.v13n1p82

URL: https://doi.org/10.5539/jpl.v13n1p82

\begin{abstract}
In recent times, threats to participatory democracy can arguably stem from a lack of strategic stability overshadowed by nuclear weapon-derived deterrence effects of a rising China and especially a relatively more belligerent resurgent Russia opposed to a Western alliance of democracies. This manuscript provides a scholarly analysis of strategic atability and illustrates some written truths that often seem incongruent with comments spoken by the same authors resulting from a hyper-politicized state of dialogue. The analysis is grounded in foundational concepts of deterrence and well-articulated in relevant policies and treaties.
\end{abstract}

Keywords: democracy, nationalism, modern nation state, stability, strategic stability, nuclear weapons, discourse and policy, political and military cooperation, xenophobia

\section{Introduction}

On 25 December 2014, Russian President Vladimir Putin signed The Military Doctrine of the Russian Federation. This document captured the Russian Federation's commitment to "taking military measures for the protection of its national interests and the interests of its allies." Additionally, it provided insight into Russia's perceived military risks and threats, intentions to pursue military-political and military-technical cooperation with foreign states, and the subject of this manuscript, the role of nuclear weapons in national defense and concerns over plans to field American ballistic missile defense (BMD) systems.

The Military Doctrine specifies one of the main tasks assigned to the Russian military is to provide "strategic (nuclear and nonnuclear) deterrence to prevent armed conflict." It further refines this statement by adding "Nuclear weapons will remain an important factor of preventing an outbreak of nuclear military conflicts involving the use of conventional arms (large-scale war or regional war)" and that the Russian Federation will deter and prevent military conflicts by "resist[ing] attempts by some states or group of states to achieve military superiority through the deployment of strategic missile defense systems (The Military Doctrine of the Russian Federation, 2014)."

The emphasis within Military Doctrine on the role of nuclear weapons and BMD deployments focuses on potential negative impacts to 'strategic stability' between Russia and the United States and the North Atlantic Treaty Organization (NATO). This relationship between nuclear weapons (offensive arms) and ballistic missile defense (defensive arms) is codified in the New Strategic Arms Reduction Treaty (New START) signed by President Dmitry Medvedev of the Russian Federation and President Barack Obama of the United States in April 2010. New START states,

"Recognizing the existence of the interrelationship between strategic offensive arms and strategic defensive arms, that this interrelationship will become more important as strategic nuclear arms are reduced, and that current strategic defensive arms do not undermine the viability and effectiveness of the strategic offensive arms of the Parties" (Treaty Between the United States of America and the Russian Federation on Measures for the Further Reduction and Limitation of Strategic Offensive Arms, 2010).

The critical nature of Russian nuclear weapons is they currently provide the only means to counter both the conventional weapons superiority and nuclear capabilities of the United States and NATO. The Russians are hostile towards plans to develop and deploy American Ballistic Missile Defense (BMD) systems within the United States and Europe, because they believe BMD will negatively impact the 'strategic stability' generated by 
their offensive nuclear weapons. The Russian believe that without the threat of retaliatory nuclear strike, there is little to do militarily to deter the United States and NATO from interfering in Russian affairs or preemptively striking Russia to initiate regime change (Defense Intelligence Agency, 2017). In addition to permeating modern day Russian military doctrine, 'strategic stability' influences treaty negotiations and justifies counterpoints to actions or proposed actions by the United States and NATO when those actions occur within, what former Russian President Dmitry Medvedev termed as, areas of Russia's "privileged interests" (Medvedev, 2008).

This manuscript establishes the genesis of 'strategic stability' and then explains how it became the cornerstone of nuclear deterrence strategies employed as part of the bipolar relationship between the Soviet Union and the United States. It later defines how these same concepts, when applied to a dynamic post-Cold War multipolar canvas achieved the same results of preventing nuclear and conventional conflict between great powers.

\section{Method}

This section illuminates the background of strategic stability, and the foundational basis of deterrence leading to a description of attaining strategic stability in the current era in the subsequent section.

\subsection{The Genesis of Strategic Stability}

The genesis of "strategic stability' is associated with the horrific effects generated by a nuclear explosion and the Cold War deterrence theories designed to drive strategies to prevent nuclear weapons use in conflicts between great powers. Henry Kissinger wrote that "It is paradoxical, however, that so much hope should concentrate on one of man's most destructive capabilities" (Kissinger, 1969). The ultimate goal of "strategic stability", according to Thomas C. Schelling and Morton H. Halperin, is to create a "balance of deterrence." They believe deterrence exists when...

"... a situation in which the incentives on both sides to initiate war are outweighed by the disincentives[a situation] is described as 'stable' when it is reasonably secure against ... perturbations" (Schelling \& Halperin, 1961).

During the Cold War, this 'balance of deterrence' created a bipolar world aligned with either of the dominant nuclear powers. According to Kenneth Waltz, deterrence was achieved in this bipolar relationship because "The United States is [was] the obsessing danger for the Soviet Union, and the Soviet Union for the U.S., since each could damage the other to an extent that no other state can match" (Waltz, 1963).

Cold War military strategists realized the nation acting first in combat with advanced offensive nuclear weapons with greater yields, responsiveness and accuracy could deliver a devastating first-strike leaving capitulation as the only rational option available for the attacked party. The destabilizing effects of a 'first strike' placed a premium on survivable retaliatory offensive capabilities such as nuclear-capable submarine launched ballistic missiles (SLBM), intercontinental ballistic missiles (ICBM), and long-range bombers. In addition to first-strike concerns, fielding BMD capabilities was seen as destabilizing. Military strategists postulated "measures to defend the homeland against incoming punitive weapons are complementary to offensive weapons of surprise attack" (Schelling \& Halperin, 1961). They believed since BMD could negate or significantly reduce the effects of a retaliatory nuclear strike, it provided incentives for the aggressor to strike first. From these deterrence theories, the strategy of mutual assured destruction (MAD) was born. The former United States Secretary of Defense Robert McNamara believed that

"No meaningful victory is even conceivable in a third unlimited world war, for no nation can possibly win a full-scale thermonuclear exchange. The two world powers that have now achieved a mutual assured-destruction capability fully realize that" (McNamara, 1968).

It was the premise of mutual vulnerability that enabled negotiations and the eventual approval and ratification of the Anti-Ballistic Missile (ABM) Treaty of 1972 between the Soviet Union and the United States.

\subsection{The Cornerstone of Nuclear Deterrence Strategies}

"Strategic stability" became the cornerstone of the bipolar relationship between the Soviet Union and the United States as the relationship evolved from the nuclear bombing of Hiroshima and Nagasaki by the United States in August 1945 to the lowering of the hammer and sickle from the flagpole atop the Kremlin on 25 December 1991 In the early years of the Cold War, stability did not exist as both the Soviet Union and the United States postured themselves to lead in the post-World War II-era as the Warsaw Pact and NATO alliance were forged. Additional instability was introduced as the Soviet Union broke the United States monopoly on atomic and thermonuclear weapons, and each nation developed and fielded advanced delivery system such as ICBMs, SLBM, and long-range bombers. 
It was not until the Cuban Missile Crisis in 1962 when the Soviet Union and the United States were at the brink of nuclear war did military competition give way to coexistence as they averted military confrontation. Some immediate steps were instituted such as the Moscow-DC Hotline, to ensure direct lines of communications between the heads of state in order to reduce the potential of nuclear conflict between them, and the approval of the Test Ban Treaty of 1963. As the USSR-US relationship matured, it entered a period of Détente when each pursued measures of cooperation to build confidence and reduce the possibility of war. Détente yielded major diplomatic achievements to include the Non-Proliferation Treaty of 1968, as well as the Anti-Ballistic Missile (ABM) Treaty and Strategic Arms Limitation Treaty (SALT) of 1972 (Young \& Kent, 2013) ushering in an era of eased tensions between the rivals. Even though a spirit of cooperation was born, both nations continued to modernize their nuclear forces, delivering new capabilities which included ICBMs and SLBM able to travel greater distances with more warheads.

Détente later gave way to perturbations in 'strategic stability' introduced by a new arms race and political turmoil within the Warsaw Pact and the Soviet Union. The new arms race delivered American intermediated-range nuclear missiles to Europe. These advanced weapon systems included the precision guided American Tomahawk ground-launched cruise missile (GLCM) which was impervious to Soviet air defenses, and the lethal responsiveness of Pershing II ballistic missile, as well as the survivable Soviet SS-20 mobile missile system. The new arms race brought forth the American Strategic Defense Initiative (SDI), a space-based anti-ballistic missile system designed to protect the United States, and potentially the Soviet Union from surprise attacks. As a concrete measure to reduce nuclear competition as a part of a new detente, Mikhail Gorbachev and Ronald Reagan signed the Intermediate Range Nuclear Forces (INF) Treaty in 1987 obligating the Soviet Union and United States to remove and destroy an entire class of nuclear weapons. Additionally, Gorbachev and George H. W. Bush signed the Strategic Arms Reduction Treaty (START) in August 1991 (Young \& Kent, 2013).

For nearly forty-five years, the Soviet Union and the United States evolved a relationship which went through phases of competition, coexistence and cooperation. The evolution put in place the means to exercise "mutual restraint, collaborative action, or exchange of facilities between potential enemies in the interest of reducing the likelihood of war, the scope of war if it occurs, or its consequences" (Schelling \& Halperin, 1961). On 1 June 1990, the Soviet Union and the United States released the Joint Statement on Future Negotiations on Nuclear and Space Arms and Further Enhancing Strategic Stability. The Joint Memo stated

"The objectives of these negotiations will be to reduce further the risk of war, particularly nuclear war, and ensure strategic stability, transparency and predictability through further stabilizing reductions in the strategic arsenals of both countries" (Bush \& Gorbachev, 1990).

\section{Results}

\subsection{Strategic Stability in the Post-Cold War-Era}

'Strategic stability' between Russia and the United States has been under attack since the end of the Cold War. Issues such as NATO expansion affected the perceived power of the Russian Federation as former Warsaw Pact members and the former Soviet Republics of Latvia, Lithuania and Estonia joined the Alliance. The Russian military power was questioned as well with the failure to put down rebels during the First Chechen War in the mid-1990s.

The most influential factors effecting the role of nuclear weapons in Russian military doctrine are centered upon the demonstration of advanced conventional weapons that played out during Operation DESERT STORM in Iraq and Operation ALLIED FORCE in the former-Yugoslavia. The result of which exposed the capability gap between Russia and the United States. The United States had the means to deliver conventional strikes achieving comparable strategic effects as nuclear weapons but without crossing the nuclear threshold. The lethality of these advanced weapons and their ability to deliver strategic effects led Vladimir Putin to say that conventional precision guided munitions (PGMs)

"are comparable to the employment of nuclear weapons in results but more acceptable in political and military terms. In this manner, the role of the strategic balance of nuclear forces in deterring aggression will gradually decline” (Putin, Byt' Sil'nymi: Garantii Natsional'noi Bezopasnosti Dlia Rossli, 2012).

But the role of nuclear weapons remains firmly embedded within Military Doctrine which states "The Russian Federation shall reserve the right to use nuclear weapons in response to the use of nuclear weapons and other types of weapons of mass destruction against it and/or it allies, as well as in the event of aggression against the Russian Federation with the use of conventional weapons when the very existence of the state is in jeopardy" (The Military Doctrine of the Russian Federation, 2014). Additionally, Deputy Minister of Defense Kokosin 
stated he believed PGMs could "augment nuclear deterrence as a point on the escalation ladder" and reduce Russia's overall reliance on nuclear weapons increasing options in time of crisis (Kokosin, 2013).

The fact that Senior Russian leaders recognize the lethality of American conventional guided munitions, as demonstrated in both Iraq and in Yugoslavia, validates Russian hesitance to accept American efforts to move towards 'global zero'. It is the Russian belief that the United States will offset 'strategic stability' in their favor if all nuclear weapons are removed since the United States has an "overwhelming military superiority in the field of high precision munitions" especially if combined with a global BMD system (Kortunov, 2011).

Today, both Russia and the United States have nuclear forces on alert in support of their respective nation's strategic deterrent mission. These forces are comprised of SSBNs, ICBMs and bomber forces (when generated). As of 2 Oct 2017, the number of Russian and American launchers and deployed nuclear warheads is $501 / 660$ and 1561 / 1393 respectively. (US Department of State, 2017). When New START goes into effect in February 2018, those numbers will be capped at 700 launchers and 1550 warheads respectively.

Nuclear weapons provide Russia a key security guarantee preventing encroachment by foreign powers and alliances, and a significant a hedge against aggression by adversaries with technologically superior weapons able to deliver strategic effects comparable to nuclear weapons (Rojansky, 2013). But according to Elbridge Colby

"Nuclear weapons remain highly significant in relations and strategic dynamics between the United States and Russia, not simply as symbols but also as instruments of coercive leverage in crisis and deadly weapons in the event of war" (Colby, 2016)

The Russian incursion into the Ukraine in 2014 provides evidence to support Colby's observation. It brings to light Putin's intent to leverage the coercive attribute of nuclear weapons to gain freedom of maneuver within Russia's areas of 'privileged interests.' In his statement with a cynical reference to the United States and NATO as "our 'partners'... should understand that it is better not to mess with us...I want to remind them that Russia is one of the strongest nuclear powers" (Putin, Remarks by President Putin at the All-Russian Youth Forum, 2014).

From a Russian perspective, 'strategic stability' is under attack by the efforts of the United States to continue development and deployment of ABM systems in United States and in Europe, most notably within what Russia perceives to be within its area of 'privileged interests' Romania and Poland. When the United States withdrew from the 1972 ABM Treaty in June 2002, it provided assurances that the system is designed to counter emerging threats from Iranian and North Korean ballistic missiles capable of delivering nuclear weapons against targets in Europe and the United States. Russia's concern is if the United States increases the numbers and capabilities of its missile defense interceptors while Russia is obligated to decrease its deployed strategic warheads the United States gains the advantage. In December 2009, Russian President Putin opined that the United States BMD plans would result in disrupting the strategic balance and in order for the balance to be restored "Russia would have to deploy greater numbers of offensive weapons, so that it would have the means to overwhelm the U.S. missile defense system" (Barry, 2009). Putin's comments on the effect of global BMD on strategic stability seem to exaggerate the effect either for possible consumption by the internal Russian audience to gain approval or to gain leverage for future negotiations. Regardless, these are games played by great powers to either deter aggression or coerce a desired end-state. This is not much different than the former Secretary of Defense Dick Cheney commenting during the DESERT STORM that "the President will have available the full spectrum of capabilities. And if Saddam Hussein is foolish enough to use weapons of mass destruction, the US response will be absolutely overwhelming and it would be devastating" (Freedman, 2003).

\section{Discussion}

Russian military doctrine has evolved since the end of the Cold War. It has reduced its reliance on nuclear weapons as a source of national power while growing its ability to leverage all elements of national power to include "political, diplomatic, legal, economic, information and other instruments of a non-violent nature" (The Military Doctrine of the Russian Federation, 2014). But the purpose for nuclear weapons and strategic stability remains true to the deterrent principals introduced during the Cold War, "prevent the outbreak of nuclear conflicts" while protecting Russian right to self-determination.

Unfortunately, as the dependence on nuclear weapons to deter great nation nuclear confrontation decreases for both the Russian Federation and the United States, the possibility for confrontation between these nations may increase as precision guided munitions and other asymmetric military capabilities become more readily available. As these capabilities emerge, strategic stability relies upon the same core functions of dialogue and negotiations used during the Cold War to inhibit the effects of changes in the geopolitical environment and technological innovation. 
The relationship between nuclear weapons, ballistic missile defense and deterrence is dependent on maintaining strategic stability amongst all the actors. In the post-Cold War era, the simple and stable environment established by the bipolar relationship between the Soviet Union and United States is gone. It is now replaced by a dominant power, the United States, and effected by a multitude of peripheral powers with and without nuclear weapons striving to achieve great nation status.

Just as during the Cold War the United States and the Soviet Union needed to overcome the great power tendency to gain power at the expense of rivals, the United States and Russia, given the lack of a functional international ruling body, need to find common ground to avert a conventional arms race that increases the potential for armed conflict between the great powers.

The complex nature of deterring conflict ranging from ballistic missiles and nuclear weapons to cyberspace and terrorist attacks at home and abroad, both depends on a diverse set of strategic deterrent capabilities to deter attack. These capabilities will require both nations to overcome the great power tendency to regard each other with suspicion and expend the intellectual and financial capital to address these new risks in order to avert conflict.

\section{Acknowledgments}

The education that lead to this self-funded research was funded by the U.S. Strategic Command's distance learning education program (Mihalik, 2018; Sands, 2017) in response to an increased need for critical thinking in the nuclear enterprise in a period of global uncertainty (Bittick, 2019; Camacho, 2018; Nakatani, 2018; Sands, 2016 \& 2018). The APC was funded by corresponding author. Special thanks to Dr. Jeni Mitchell, a teaching fellow and postdoctoral researcher at King's College London specializing in non-state armed groups and civilian victimization, with a particular focus on the post-communist space and the greater Middle East. Her support and guidance was key to the research in this manuscript. Authorship has been limited to those who have contributed substantially to the work reported: conceptualization, C.T.K.; methodology, C.T.K.; formal analysis, C.T.K.; investigation, C.T.K.; supervision, J.M.; validation, J.M.; resources, T.S; data curation, C.T.K.; writing —original draft preparation, C.T.K.; writing - review and editing, T.S.; funding acquisition, T.S., Please turn to the CRediT taxonomy for the term explanation. T.S. is not a tenured faculty member of Columbia University; rather he is the Associate Dean of the Naval Postgraduate School's Graduate School of Engineering and Applied Sciences. In order to avoid legal jeopardy, T.S. publishes government-funded research under his association with the Naval Postgraduate School, while publishing non-government funded research under his continuing associations with Stanford and Columbia Universities.

\section{References}

Barry, E. (2009, December 30). Putin Sounds Warning on Arms Talks. New York Times.

Bittick, L., \& Sands, T. (2019). Political Rhetoric or Policy Shift: A Contextual Analysis of the Pivot to Asia. Journal of Social Sciences, 15, 92-125. https://doi.org/10.3844/jssp.2019.92.125

Bush, G., \& Gorbachev, M. (1990, June 1). UCSB. Retrieved from http://www.presidency.ucsb.edu/ws/?pid=18541

Colby, E. (2016, February 26). The Role of Nuclear Weapons in the U.S.-Russian Relationship. Carnegie Endowment for International Peace.

Fitzgerald, M. C. (1990). Marshal Ogarkov and the Revolution in Soviet Military Affairs. Defense Analysis, 6(2), 167-191. https://doi.org/10.1080/07430179008405444

Freedman, L. (2003). The Evolution of Nuclear Strategy (3rd ed.). London: Palgrave Macmillan. https://doi.org/10.1057/9780230379435

Friedman, T. L. (1998, May 2). Foreign Affairs; Now a Word from X. New York TImes. Retrieved from http://www.nytimes.com/1998/05/02/opinion/foreign-affairs-now-a-word-from-x.html

Hildreth, S. A., \& Woolf, A. E. (2010, May 25). Ballistic Missile Defense and Offensive Arms Reductions: A Review of teh Historical Record. Washington DC: Congressional Research Service.

Johnson, D. (2015, April). Russia's Approach to Conflict--Implications for NATO's Deterrence and Defence. NATO Research Paper. Rome, Italy: NATO Defense College.

Kissinger, H. (1969). Nuclear Weapons and Foreign Policy. New York: W. W. Norton \& Company, Inc.

Koblentz, G. D. (2014). Strategic Stability in the Second Nuclear Age. Council on Foreign Relations.

Kokosin, A. A. (2013). Politiko-Voenniie I Voenno-Strategicheskiie Problemy Natsional'noi Bezopasnosti. pp. 
213-223.

Kortunov, S. (2011). Yaderniy Gambit Baraka Obamy. Indeks Bezopasnosti Number 3, 42.

Lebedev, Y. V., Liurov, I. S., \& Nazurenko, V. A. (1991, November-December). Voina v Zone Persidskovo Zaliva: Uroki 1 Vyvody. Voennaya Mysl, (11-12), 109-117.

McNamara, R. S. (1968). The Essence of Security. The University of Michigan: Harper \& Row.

Mearsheimer, J. J. (2014). The Tragedy of Great Power Politics. New York: W. W. Norton and Company, Incorporated.12

Medvedev, D. (2008, August 31). President of Russia. Retrieved from Events: http://en.kremlin.ru/events/president/transcripts/page/275

Mihalik, R., Camacho, H., \& Sands, T. (2018). Continuum of Learning: Combining Education, Training, and Experiences. Education, 8(1), 9-13.

Nakatani, S., \& Sands, T. (2018). Eliminating the Existential Threat from North Korea. Science and Technology, $8(1), 11-16$.

Oliker, O. (2015, January 15). Rand Corporation. Retrieved from https://www.rand.org/search.html?query=Russia\%27s\%20New\%20Military\%20Doctrine $\% 20$

Putin, V. (2012, February 20). Byt' Sil'nymi: Garantii Natsional'noi Bezopasnosti Dlia Rossli. Rossikaya Gazeta. Retrieved from http://www.rg.ru/2012/02/20/putin-armiya.html

Putin, V. (2014, August 29). Remarks by President Putin at the All-Russian Youth Forum. Retrieved from http://news.kremlin.ru/news/46507

Rojansky, M. (2013). Russia and Strategic Stability. In E. A. Colby, \& M. S. Gerson (Eds.), Strategic Stability: Contending Interpretations (pp. 295-342). Carlisle Barracks: Strategic Studies Institute and the US Army War College Press.

Sands, T., \& Mihalik, R. (2016). Outcomes of the 2010 \& 2015 Nonproliferation Treaty Review Conferences. World Journal of Social Sciences and Humanities, 2(2), 46-51.

Sands, T., Camacho, H., \& Mihalik, R. (2017). Education in Nuclear Deterrence and Assurance. $J$ Def Manag, 7 , 166. https://doi.org/10.4172/2167-0374.1000166

Sands, T., Camacho, H., \& Mihalik, R. (2018). Nuclear Posture Review: Kahn Vs. Schelling...and Perry. Journal of Social Sciences, 14, 145-154. https://doi.org/10.3844/jssp.2018.145.154

Sands, T., Mihalik, R., \& Camacho, H. (2018). Theoretical Context of the Nuclear Posture Review. Journal of Social Sciences, 14, 124-128. https://doi.org/10.3844/jssp.2018.124.128

Schelling, T. C., \& Halperin, M. H. (1961). Strategy and Arms Control. New York: The Twentieth Century Fund.

Sinovets, P., \& Renz, B. (2015, July). Russia's 2014 Military Doctrine and beyond: threat perceptions, capabilities and ambitions. NATO Defense College, Reaearh Division, Rome.

The Military Doctrine of the Russian Federation. (2014, December 25). Retrieved from https://www.rusemb.org.uk/press/2029

Treaty Between the United States of America and the Russian Federation on Measures for the Further Reduction and Limitation of Strategic Offensive Arms. (2010, April 08). Retrieved from https://www.state.gov/documents/organization/140035.pdf

Trenin, D. (2014, December, 29). Carnegie Moscow Center. Retrieved from Commentary: http://carnegie.ru/commentary/57607

US Department of State. (2017, October 2). Retrieved from New START Fact Sheets: https://www.state.gov/t/avc/newstart/274550.htm

Waltz, K. N. (1963). The Stability of a Bipolar World. Daedalus, 93(3), 881-909.

Young, J. W., \& Kent, J. (2013). International Relations Since 1945: A Global History (2nd ed.). Oxford, United Kingdom: Oxford University Press. 


\section{Copyrights}

Copyright for this article is retained by the author(s), with first publication rights granted to the journal.

This is an open-access article distributed under the terms and conditions of the Creative Commons Attribution license (http://creativecommons.org/licenses/by/4.0/). 